\title{
A Simple Fix for a Complex Problem? Comments on Morgan Ricks, The Money Problem: Rethinking Financial Regulation
}

\author{
${ }^{1}$ Vanderbilt University Law School, Nashville, TN 37203, USA, E-mail: margaret.blair@vanderbilt.edu
}

\begin{abstract}
:
The financial crisis of 2007-2009 left scholars and policy analysts scrambling to explain what went wrong. While a variety of stories have been told, none have seemed like they could account for the magnitude of the collapse in securities values, or the devastation the collapse caused to the performance of whole economies around the globe, nor could they offer a clear path to reform. Legislation passed to reform the financial system in the U.S. is extraordinarily complex, and still very controversial. Now, however, Morgan Ricks' new book, The Money Problem: Rethinking Financial Regulation, cuts through the complexity to offer a relatively simple but compelling explanation - the crisis was a consequence of an old-fashioned run on the "bank", which, in this case, was the shadow banking system rather than regular banks. The solution is the same as the solution that prevented major financial crises in the U.S. from the 1930s to 2007 - government insurance of "money claims" and stricter regulation of firms that are allowed to issue money-like claims.
\end{abstract}

Keywords: money, financial regulation, banks

DOI: 10.1515/ael-2017-0042

The Money Problem. Perspectives on Money, Banking and Financial Regulation

1 "Banking, Money and Credit: A Systemic Perspective" by Yuri Biondi, https://doi.org/10.1515/ael-20170047

2 "A Simple Fix for a Complex Problem? Comments on Morgan Ricks, The Money Problem: Rethinking Financial Regulation" by Margaret M. Blair, https://doi.org/10.1515/ael-2017-0042

3 "Morgan Ricks: “The Money Problem: Rethinking Financial Regulation"” by Philippe Moutot, https://doi.org/10.1515/ael-2017-0029

4 "Financial Stability and Money Creation: " by Thorvald Grung Moe, https://doi.org/10.1515/ael-2018-0010

5 “The Money Problem: A Rejoinder” by Morgan Ricks, https://doi.org/10.1515/ael-2018-0018

In the wake of the financial crisis of 2007-2009, policy analysts and scholars in the fields of finance and economics rushed to write books and articles about what went wrong. The early works pointed to culprits such as banks that were "too big to fail" (Johnson \& Kwak, 2010); federal bank regulations that supposedly required banks to increase mortgage-lending activity in high risk neighborhoods and to high-risk populations (Wallison, 2015); reckless lending by mortgage brokers (Mian \& Sufi, 2009); excessive borrowing by irresponsible homeowners (Khandani, Lo \& Merton, 2013; Mian \& Sufi, 2009); promiscuous financing of these mortgages by Fannie Mae and Freddie Mac (Wallison, 2015); irresponsible and even corrupt assessments of debt quality by credit ratings agencies (United States Senate Permanent Subcommittee on Investigations, 2011); mind-numbing complexity of derivatives constructed to allow financial institutions to bundle, repackage, and bet on portfolios of poorly performing mortgages (United States Senate Permanent Subcommittee on Investigations, 2011); excessive use of leverage by banks and other financial institutions (Adrian \& Shin, 2009; Blair, 2010-2011; Turner, 2012); poor corporate governance at financial institutions (Bebchuk, Cohen \& Spamann, 2010; United States Senate Permanent Subcommittee on Investigations, 2011); and even low-interest rate policies by central banks (Taylor, 2009).

No doubt there is sufficient blame to go around, and some truth in all of these charges, but none of these stories seemed like they could account for the magnitude of the collapse in securities values, or the devastation the collapse caused to the performance of whole economies around the globe. And none presented a simple or clear path to reform that could prevent such a crisis from occurring again. Nonetheless, in the U.S., reform 
legislation was passed in the summer of 2010. The Dodd-Frank Wall Street Reform and Consumer Protection Act (Publ. L. 111-203) was incredibly complex: more than 800 pages long, it was broken out into 16 titles, required the creation of several new agencies and regulatory structures, and, according to one law firm, called for creating 243 new rules, conducting 67 studies, and issuing 22 periodic reports (Polk, 2010). ${ }^{1}$

Now, nearly a decade after the financial crisis began, a new voice has emerged that cuts through the complexity, with a simple story about what went wrong, and a straight-forward and compelling proposal about how we need to fix it. In his new book, The Money Problem: Rethinking Financial Regulation (Ricks, 2016), Prof. Morgan Ricks tells a story about old fashioned bank runs, and the factors that cause them. In doing so, he challenges core concepts and basic theories that have long been relied upon in the fields of bank regulation, macroeconomics, and finance, especially with regard to the operation of so-called "money markets." These theories, and the regulatory mechanisms associated with them failed so spectacularly in the run-up to the crisis that they cry out for fundamental rethinking. Ricks lays the groundwork for that process with a new theoretical framework, and some relatively straightforward reforms that offer to put in place a much less vulnerable institutional framework for money and banking policy in this country, and globally.

Ricks' basic thesis is that the financial crisis was a classic example of a "financial panic," a phenomenon defined by Federal Reserve Board Chairman Ben Bernanke at the time as "a generalized run by providers of short-term funding to a set of financial institutions" (Bernanke, 2009; Ricks, 2016, p.93). Financial panics, Ricks claims, are uniquely troubling events because they almost invariably lead to catastrophically deep recessions from which economies recover extremely slowly. Ricks argues that panics cause the ensuing recessions (rather than simply being symptomatic of the recessions, or of some other underlying cause). If this is correct, then if regulators can prevent panics, they can go a long way toward eliminating or at least mitigating an important source of severe economic recessions. He cites data and empirical research on financial crises and economic downturns over the centuries and across numerous economies for support for this argument, but he does not, himself, do econometric or statistical testing of his theory. Instead, his goal is to rethink how economists, regulators, and policy-makers think about the role of money and short-term funding markets in modern economies.

Ricks' analysis is both radical and traditional. It is radical in that it directly confronts most of the theorizing about money markets and macroeconomics that has been done in the last five or six decades. Although he doesn't say this directly, his critique is especially challenging to theoretical work based on "rational expectations" models, which assume that monetary policy cannot systematically "fool" financial markets (Krugman \& Wells, 2009, p.483). In such (theoretical) markets there is no "money illusion." Governments cannot stimulate the economy by expanding the money supply, for example, because market actors will understand that additional money in the system will just drive up prices. Thus the injection of money into the system will only cause inflation.

Macroeconomic models based on this line of thinking generally assume that markets clear without considering the often messy details of the way that financial markets and systems of exchange actually work. The value that assets take in such hypothetical markets is solely a function of expected cash flows, not irrational fads, or stampedes, or collective action problems. There are no concerns about liquidity in the system as a whole in a rational expectations macro model that might cause actors to sell assets at less than their "true" value. These models include only a stylized but rudimentary banking system (to match savers to borrowers at a market-clearing interest rate). These theoretical approaches, hence, have no way of anticipating and studying the phenomenon of bank runs or "panics." Ricks, however, provides a simple, game-theoretic way to think about what causes panics. His model does not rely on irrationality, but it has radical implications for the role of money and banking in economies.

Ricks' analysis is traditional in the sense that it returns to the thinking of such theorists as John Maynard Keynes, Milton Friedman, Anna Schwartz, Joseph A. Schumpeter, and Walter Bagehot for a basic understanding of what it is that banks do, and how a banking system affects the functioning of the economy as a whole. If panics are the problem, as he says, then the regulation of banking and finance (at least regulation aimed at financial stability) should be focused on preventing panics. The device to achieve this is not exotic or complicated, but familiar: provide federal insurance for all money-like securities that are susceptible to runs, just as we now provide federal insurance for bank deposits accounts of $\$ 250,000$ or less, and regulate entry into the business of money creation.

To explain and justify this policy proposal, the largest part of Ricks' book explains why we should think of all short-term debt instruments that trade in the so-called "money markets", as well as packages of derivatives that replicate the returns on such instruments, as "money," or "money claims." In the years and months leading to the Financial Crisis, these are the kinds of instruments that were issued and traded by players in the financial markets who, collectively, have been called the "Shadow Banking System." Ricks tells us that, if we understand what it is that banks do, we will understand that players in the Shadow Banking System were actually engaged in the business model of banking. They were borrowing money on a very short-term basis (such as overnight), and using the proceeds from that financing to invest in ventures and securities that are much longer term. In 
doing so, they were taking on enormous liquidity risk - they needed to roll over their funding daily, and if, for any reason, the short-term funding dried up, they were likely to default on their obligations unless they could sell their long-term assets quickly and without having to accept a greatly discounted price. Players in the Shadow Banking sector were not taking the full cost of this risk into account in the rates of return they were demanding when they invested in short-term instruments or loaned out the proceeds of their short-term funding, because much of the risk is externalized - financial institutions and their investors were implicitly relying on the idea that the U.S. government, alone or in collaboration with other western countries, would not allow the whole system to fail. They were engaging in this risky business on a completely unregulated basis. In fact, they were strategically structuring their transactions and securities to take advantage of implicit "insurance" while avoiding regulations. And regulators were not only not imposing constraints on this activity as it was being carried out in the Shadow Banking sector, they were not even monitoring it very closely. ${ }^{2}$

Ricks' argument is that the short-term instruments issued and traded by financial firms in the run-up to the crisis looked, smelled, acted like, and performed the same economic function as money (Ricks labels all such instruments "money claims."), and the institutions that issued them were susceptible to runs in exactly the same way that banks used to be susceptible to runs - and experienced them with some frequency - prior to the establishment of deposit insurance with the Banking Act of 1933.

Insuring short-term securities without regulating the issuers of those securities, however, is a recipe for massive "moral hazard" among Shadow Bankers. So the other half of Ricks' proposal for stabilizing the financial system is that the issuance of such securities would have to be regulated in the same way that banks are regulated now. Ricks recognizes that such a proposal will not be popular among financial institutions in the Shadow Banking sector, and their executives, who made a tremendous amount of money by engaging in banking-type transactions in the years leading up to the crisis. But Ricks believes that much of the other financial stability regulation, such as that in the Dodd-Frank Act, could be rolled back if we have a reliable way to regulate and limit the creation of money and money-like instruments, and thereby prevent runs.

Ricks' presentation of the theoretical basis for his reform proposals in the first four chapters of his book is laid out in plain language and seems so simple that a reader who doesn't know Ricks, and is not already sophisticated about scholarship on money and banking, might get the impression that Ricks must surely be naïve, and unschooled about the complex ways of sophisticated financial markets. ${ }^{3}$ As the book progresses, however, Ricks dives deeper and deeper into institutional detail about the operation of sophisticated markets. He tells us that it is difficult to regulate certain markets by trying to regulate the issuance of certain kinds of securities because it is generally possible to construct combinations of derivatives that can replicate the returns (and risks) from the regulated securities, while escaping regulation. And he gives detailed examples of how this can be done. He also explains details of various bank regulations and how they are manipulated by shadow banking issuers. By the end of the book, any doubt about Ricks' sophistication must surely be erased when he reviews in Chapter 10, some detail about how other regulations could be scaled back if the banking regulators could impose an effective limit on who is entitled to issue money-like instruments, and on the total amount of such money-like instruments that could be in circulation.

For example, Ricks compares his simple approach to panic-proofing the financial sector (provide federal government insurance for all money claims, and sharply restrict the entry of financial institutions into the business of money claim creation) to further regulatory steps to address two other financial market "pathologies," "too big to fail" and "debt-fueled bubbles."

“... FDIC vice chair Thomas Hoenig has advocated regulatory steps that would force a breakup of the largest US financial institutions, thereby addressing the too big to fail problem. Other policy experts have promoted similar measures. Likewise, it should come as no surprise that the 'debt cycle' theorists ... tend to favor system-wide limits on debt and leverage. Thus Hyman Minsky has argued that central banks should 'continuously "lean against" the use of speculative and Ponzi finance.' John Geanakoplos suggests "empowering a "leverage supervisor" who could simply forbid loans at too high leverage in ebullient times.' Reinhart and Rogoff, who also lean toward the debt cycle view at times, advocate creating 'a new independent international institution' that would 'enforce regulations relating to leverage.' Mian and Sufi call for increased use of equity-like contracts rather than debt. And Paul Krugman argues for 'higher capital ratios for banks, limits on risky lending, but also perhaps limits for borrowers too, such as maximum loan-to-value ratios on housing and restrictions on second mortgages.' This, he says 'would guard against bubbles and excessive leverage.' My argument is that we probably should not do these things - at least not in the first instance. A more sensible approach to money creation might very well alleviate these other pathologies" (Ricks, 2016, p.260-261, citations omitted).

While the diagnosis and prescribed cure are conceptually simple, they will not be politically easy to implement. As policy-makers going all the way back to Alexander Hamilton have understood, the business model of banking can be very lucrative - a license to engage in banking is literally a license to create money. Thus participants 
in the "shadow banking" sector, including brokerage houses, money market funds, etc. will not easily give up the right to engage in this profitable activity. The carrot that Ricks offers to possibly offset the sting of the stick is that many of the Dodd-Frank reforms, and even some pre-Dodd-Frank regulations, could be relaxed if the right to create "money claims" could be reined in and confined only to regulated institutions licensed to do this.

The other factor that will make reform difficult is that policy analysts who have focused on other problems with the financial system may not be willing to give up their favorite proposed fixes. ${ }^{4}$ While I love the simplicity and elegance of Ricks' analysis, I am concerned that it does not place enough emphasis on the role played by the sheer magnitude of borrowing in the financial system in the years and months leading up to the crisis. Mian and Sufi (2014), believe, for example, that a massive run up in household debt generated the bubble in housing prices. When the bubble burst, and housing prices collapsed, households were compelled to slam the breaks on further borrowing for consumption. This contributed to what Mian and Sufi claim it was the primary cause of the recession. They note that household debt in the U.S. doubled between 2000 and 2007, and the ratio of debt to income shot up from 1.4 to 2.1. They claim that a similar pattern preceded the Great Depression in the U.S., as well as the collapse of financial bubbles in other countries, such as in Japan in the 1990s (Mian \& Sufi, 2014, p.3-9).

No one knows what the optimal amount of debt financing is relative to GDP. Cecchetti and Kharroubi (2012) have done work that suggests that when total private $\mathrm{debt}^{5}$ is greater than GDP in an economy, or when the financial sector's share in total employment exceeds $3.5 \%$, greater growth in the financial sector begins to impede growth in productivity. Although this work is not (yet) definitive, it is certainly suggestive. Moreover, it seems plausible to me that the huge run-up in borrowing and lending in the U.S. from around 2003 to 2007 contributed to a bubble in the prices of the real assets behind all that lending, especially mortgages on residential and business property. ${ }^{6}$ As to whether the bubble was the problem, or only the ensuing panic, ask yourself whether a "panic" at a single financial institution would have propagated through the financial system into a massive financial crisis, a massive crisis of confidence in the value of underlying assets, if asset prices had not spiraled so far upwards in the previous few years? I doubt it. In other words, while panics can happen in theory without a prior surge in lending and a bubble in asset prices, it seems likely to me that the asset price bubble provides the tender that can explode into flames when some event triggers doubt about whether all the debt can be repaid.

Ricks counters that asset bubbles and crashes do not always lead to massive recessions. The stock market collapsed briefly in the fall of 1987, for example, and no recession occurred in the months afterwards. Equity values in the "dot.com" sector also spiraled upwards, and then crashed in 1999-2001, with no ensuing recession. I would argue, however, that a run-up, and subsequent crash in stock prices should not be expected to produce the same real effects on the economy as a run-up and subsequent crash in housing prices for two reasons. First, people were not living in their dot.com stocks. They would not be evicted onto the streets if their bet on a start-up technology company failed. And secondly, a collapse in value of their houses means, at best, that homeowners cannot use their houses to finance further consumption, and at worst that they lose their houses, and whatever portion of their net worth the house had represented. Thus a collapse in housing prices would likely lead to a much more dramatic fall in consumption, which is the largest component of GDP, than a collapse in the prices of speculative securities.

It is not obvious to me that limiting the institutions that can create money claims, and providing federal government insurance for all money claims, will necessarily prevent asset bubbles and crashes. Indeed, Ricks does not claim that it would have this effect - there is no reason to believe that the dot.com bubble and bust was fueled by excessive creation of money and money claims, for example. But if Ricks' proposals could be implemented, it would go a long way toward preventing a repeat of the disastrous events of 2007-2009. And that would be a very worthwhile outcome.

\section{Notes}

1 Ricks (2016), p.250) estimates that Dodd-Frank calls for 390 rule-makings, and the final rule releases are expected to occupy over 15,000 pages in the Federal Register by the time all of that rule-making is complete.

2 As an indication of the utter absence of official attention to the activities of the Shadow Banking system, the Federal Reserve stopped measuring, monitoring and reporting a measure of the money supply called "M3", which picked up some, but not all of the activity in the Shadow Banking sector, in the spring of 2006. Ricks (2016), p.9, mentions this policy change. I discuss it at some length in Blair (2010-2011), p.270-273.

3 Ricks (2016) anticipates in the Preface (xiii) that some readers might initially think him naïve, quoting Steve Jobs as saying that "It takes a lot of hard work ... to make something simple, to truly understand the underlying challenges and come up with elegant solutions." And at one point in the Introduction (17), Ricks says, "I don't think I am naïve about the potential for 'regulatory arbitrage' - a fancy term for 'avoidance.' I used to do it for a living." 
4 I don't count myself as a policy-maker, but if I were, I would not accept Ricks' proposals as a total solution to the problem of financial instability.

5 Their analysis was robust to measurements of "private credit by deposit money banks to GDP" and "private credit by deposit money banks and other financial institutions to GDP," both extracted from World Bank Financial Structure and Development Database.

6 I made this argument in Blair (2010-2011), p.269.

\section{References}

Adrian, T. \& Shin, H. S. (2009).The shadow banking system: Implications for financial regulation. Federal Reserve Bank of N.Y. Staff Report No. 382.

Bebchuk, L. A., Cohen, A. \& Spamann, H. (2010). The wages of failure: executive compensation at Bear Stearns and Lehman, 2000-2008. Yale Journal on Regulation, 27, 257-282.

Bernanke, B. S. (2009). Reflections on a year of crisis. Remarks at the Federal Reserve Bank of Kansas City's Annual Economic Symposium, Jackson Hole, Wyoming Aug 21.

Blair, M. M. (2010-2011). Financial Innovation, leverage, bubbles and the distribution of Income. Review of Banking and Financial Law, 30, 225311.

Cecchetti, S. C. \& Kharroubi, E. (2012). Reassessing the impact of finance on growth. BIS Working Papers, no. 381.

Polk, D. (2010).Summary of the Dodd-Frank Wall Street Reform and Consumer Protection Act, passed by the House of Representatives on June 30, 2010, July 9.

Dodd-Frank Wall Street Reform and Consumer Protection Act (2010). Pub. L. 111-203.

Johnson, S. \& Kwak, J. (2010). 13 bankers: The wall street takeover and the next financial meltdown. New York: Random House.

Khandani, A. E., Lo, A. W. \& Merton, R. C. (2013). Systemic risk and the refinancing ratchet effect. Journal of Financial Economics, 108(1), 29-45.

Krugman, P. \& Wells, R. (2009). Macroeconomics (2nd.). New York, NY: Worth Publishers.

Mian, A. \& Sufi, A. (2009). The consequences of mortgage credit expansion: Evidence from the U.S. mortgage default crisis. Quarterly Journal of Economics, 124(4), 1449-1496.

Mian, A. \& Sufi, A. (2014). House of debt: How they (and you) caused the great recession, and how we can prevent it from happening again. Chicago, IL: University of Chicago Press.

Ricks, M. (2016). The money problem: rethinking financial regulation. Chicago, IL: University of Chicago Press.

Taylor, J. B. (2009). Cetting off track: How government actions and interventions caused, prolonged, and, worsened the financial crisis. Stanford, CA: Hoover Institution Press.

Turner, A. (2012). Monetary and financial stability: Lessons from the crisis and from classic economic texts. Speech at South African Reserve Bank, Nov. 2.

United States Senate Permanent Subcommittee on Investigations. (2011).Wall street and the financial crisis: Anatomy of a financial collapse Carl Levin and Tom Coburn, May 10.

Wallison, P. J. (2015). Hidden in plain sight: What really caused the world's worst financial crisis and why it could happen again. Washington, DC: Encounter Books. 